University of Nebraska - Lincoln

DigitalCommons@University of Nebraska - Lincoln

2001

Finding the Meanings of College Drinking: An Analysis of Fraternity Drinking Stories

Thomas Workman

University of Nebraska - Lincoln

Follow this and additional works at: https://digitalcommons.unl.edu/commstudiespapers

Part of the Communication Commons

Workman, Thomas, "Finding the Meanings of College Drinking: An Analysis of Fraternity Drinking Stories" (2001). Papers in Communication Studies. 3.

https://digitalcommons.unl.edu/commstudiespapers/3

This Article is brought to you for free and open access by the Communication Studies, Department of at DigitalCommons@University of Nebraska - Lincoln. It has been accepted for inclusion in Papers in Communication Studies by an authorized administrator of DigitalCommons@University of Nebraska - Lincoln. 


\title{
Finding the Meanings of College Drinking: An Analysis of Fraternity Drinking Stories
}

\author{
Thomas A. Workman \\ NU Directions \\ University of Nebraska-Lincoln
}

\begin{abstract}
College drinking has traditionally been studied from a public health perspective that attempts to quantify behavior as a means toward description, explanation, and intervention. This article offers a critical and cultural approach to understanding the meanings and functions of high-risk drinking and the ways in which those meanings are reproduced within the culture. Data were collected via an ethnographic study of fraternity members at a large midwestern university to explore the communication of excessive drinking norms. Viewed from various narrative and structural theories, the study examines collected drinking stories as a source for analyzing the construction of meanings surrounding drunkenness for the fraternity subculture. Five themes emerged as functions of drunkenness for the culture. Implications for prevention are discussed.
\end{abstract}

Although collegiate drinking behaviors and consequences have received attention from researchers and policymakers alike, the lion's share of study is conducted from outside the realm of communication studies. In most efforts, social scientists attempt to quantify a set of behaviors and determine cause, motive, and effect through the lens of traditional social science methodology (Anderson, 1994; Ewing \& Rouse, 1978; Gross, 1993; Lichtenfield \& Kayson, 1994; Mills, Sirgo, \& Hartjes, 1993; Robbins, 1993; Slicker, 1997). Recent quantification of drinking behavior has reified the label of "binge drinking" (Wechsler, Dowdall, Davenport, \& DeJong, 1993; Wechsler, Dowdall, Maener, Gledhill-Hoyt, \& Lee, 1998; Wechsler, Lee, Kuo, \& Lee, 2000), centering it within a public health construction of collegiate drinking as a social problem (Workman, 1998).

Requests for reprints should be sent to Thomas A. Workman, NU Directions, University of Nebraska—Lincoln, 200 Nebraska Union, Lincoln, NE 68588. E-mail: tworkman3@unl.edu 
The majority of study surrounding collegiate binge drinking has focused on attempts to quantify specific drinking behaviors, motivations, and intervention strategies (Anderson, 1994; Carey, 1993; Corbin, McNair, \& Carter, 1996; Donohew et al., 1999; Gross, 1993; Haines, 1996; Klein, 1994; Lederman, 1993; Lichtenfield \& Kayson, 1994; Mills et al., 1993; Monroe, 1996; Perkins, Meilman, Leichliter, Cashin, \& Presley, 1999; Slicker, 1997; Smeaton, Josiam, \& Dietrich, 1998; Straus \& Bacon, 1953; Wechsler et al., 1993; Wechsler, Dowdall, Davenport, \& DeJong, 1994; Wechsler et al., 1998; Wechsler, Isaac, Grodstein, \& Sellers, 1994; Wechsler, Molnar, Davenport, \& Baer, 1999; Williams \& Clark, 1998). Although individual statistics vary, studies on contemporary alcohol use in college have indicated that a large percentage of college students get drunk on a "regular" basis, with little differentiation between their first and subsequent years at school (Carey, 1993; Gross, 1993; Klein, 1994; Slicker, 1997; Wechsler, Dowdall, et al., 1994). Consistently, the Greek system is identified as having the largest percentage of binge drinking behavior.

As a result, Greek students are frequently used as participants in survey-based research (Cashin, Presley, \& Meilman, 1998; Harrington, Brigham, \& Clayton, 1999; Larimer, Irvine, Kilmer, \& Marlatt, 1997; Meilman, Leichliter, \& Presley, 1999). Borsari and Carey (1999), in an effort to synthesize the literature surrounding fraternity drinking, identified five recurring themes in the literature from 1980 to 1998 . They are (a) the continuity between high school and college drinking, (b) the self-selection of heavy drinkers into environments that support heavy drinking, (c) the central role of alcohol in fraternity socialization, (d) the misperception of drinking norms, and (e) the enabling environment of the fraternity house. Several studies have indicated that students binge drank to (a) have a good time with friends, (b) get drunk, and (c) celebrate (Anderson, 1994; Borsari \& Carey, 1999; Lichtenfield \& Kayson, 1994; Mills et al., 1993).

Each of these studies indicated that students find a social pleasure in alcohol use, follow social pressures toward excessive drinking as the norm, and see drinking as an essential element in recreation. Likewise, more recent studies of cognitive and attitudinal factors of alternatives to binge drinking found that negative expectations about engaging in low-risk alternatives was related to avoiding those alternatives (Turrisi, 1999). Although a clear social connection has been identified, there have been limited attempts to explore the construction of meanings to excessive drinking. In short, society has yet to ask what messages between students exist, how those messages reproduce binge drinking norms, and how those messages are more effective than our public health messages framing the activity as dangerous or promoting moderation.

Actions such as binge drinking can be seen as a form of discourse that operates within a larger intertextual web of culture, where meanings are constructed to perpetuate and normalize dominant interpretations of cultural practices (Fiske, 1989). Rather than investigating individual response as the key source of data, the critical 
and cultural analyst looks at the discourse surrounding the practice, utilizing the narratives and the observed behavior of the culture as text that, in its associations and functions, provides a sense of "motive" to the behavior (Burke, 1973; Gusfield, 1989).

The purpose of this study is to identify the construction of collegiate binge drinking from within the culture, looking specifically at the fraternity. The study identifies a set of performances (drinking behaviors) that are given meaning through their representations as narratives in the form of drinking stories. These narratives serve as a central force to the construction of social reality and establish a set of meaningful practices for members of the culture. My argument is that high-risk drinking behavior, regardless of its outcome, is constructed by the collegiate culture as a positive, functional activity. The task for this study is to identify the signification that produces this interpretation of a potentially deadly activity.

I first outline the theoretical grounding necessary for the interpretation of cultural practices as discourse. After establishing the methodology of data collection, I identify five theme stories found in the fraternity culture at a large Midwestern university. Finally, I discuss several implications of these findings for prevention efforts, and make recommendations for future study.

\section{CULTURAL PRACTICES AS PERFORMANCE DISCOURSES}

The dramaturgic perspective views social practices as performances in which meanings are expressed to both the self and affirmed by a set of observers (Goffman, 1959). Performances are idealized to represent the beliefs of the society (Burke, 1945). Behaviors associated with drunkenness are socially learned and not strictly physiological (Heath \& Cooper, 1981). Instead, drunken behaviors are learned socially, although often unconsciously (Bourdieu, 1990). In cultural terms, performances become discourses that represent an interpretation of intertwined cues observed by the social actor (Carey, 1989).

The performance provides an opportunity for feedback by others within the culture, which, through confirmation or denial, establishes another essential set of cues for social behavior. Fiske (1989) defined this as a process of "reading," although he maintained that the notion of cultural texts must be seen as broad and interrelated. Performances, then, serve an important function in that they establish meanings for a group and concretize those meanings as social practices. In this way, social performances can be viewed as influencing further action.

One task is the identification of key sites of meaning formation, and here, narrative theory is useful. Narrative theories suggest that storytelling serves the cultural function of encouraging audience enactment (Lucaites \& Condit, 1985). Lieblich, Tuval-Mashiach, and Zilber (1998) stated: Notwithstanding the debates about its 
factual grounding, informative value, or linkage to personal identity, the life story constructs and transmits individual and cultural meanings. People are meaning-generating organisms; they construct their identities and self-narratives from building blocks available in the common culture, above and beyond their individual experience (pp. 8-9).

Therefore, stories become an essential tool to develop interpretations of social actions and situate the actions into a specific construction of reality. In the telling of the story, the culture creates a full set of mirrored cues for future social action.

However, there is another aspect of narratives that speak well to the phenomenon of the excessive drinking found within groups such as the fraternity. The habitus theory of Bourdieu (1990) utilized the metaphor of "game" to explain the structure of discourse as a set of objective demands that "impose themselves on those people, and those people alone, who, because they have a feel for the game, that is, for the immanent necessity of the game, are prepared to perceive them and carry them out" (p. 63). In other words, the use of narratives provides a recursive reality for individuals; a set of implied, unquestioned rules for social actors that are followed uncritically and passed along as inherent within the social structure. Behaviors are signified as routine and are reified without thought or reflection. Never overtly stated, the rules of the habitus are illustrated through the stories told and accepted.

Applying this theoretical foundation to the fraternity culture suggests that performance stories, when assembled collectively, tell their own story about the unquestioned functions and meanings beneath established drinking practices. The goal of this investigation is to collect the common narratives of excessive drinking told within the fraternity setting and, through linguistic analysis, identify the themes that emerge as meaningful within the culture.

\section{METHODS OF DATA COLLECTION}

Members of 17 fraternities that had residence houses on campus were contacted through their presidents via letter and offered the opportunity to participate in group interviews in which they could "share their favorite drinking stories." Five fraternity houses were chosen randomly for the interviews, which took place within the members' fraternity house. To avoid face-saving responses, group interviews were held spontaneously (with president approval) with any members of the fraternity who were present and willing at the time that the interviewer appeared at the house. Groups ranged in size from 2 to 6 members for a total of 21 respondents. Interviews were conducted as casual conversations filled with laughter to imitate the settings where drinking stories are told.

In addition to group interviews, a female confederate was used for participant observations of fraternity parties at a sixth fraternity. The confederate was a girlfriend 
of a fraternity officer, attended parties regularly, and was well accepted by the subculture. Data from her observations were collected via interview.

Data were then analyzed linguistically from transcripts. Noted were similarities in term clusters and descriptions of experience. Five such metanarratives emerged. Drunkenness was the common theme for all stories; terms such as trashed, loaded, and blitzed were regularly used to frame the stories.

\section{EMERGING THEMES: THE MEANINGS OF DRUNK PERFORMANCES}

\section{The Adventure Story: Drunkenness as Risk Taking}

One function of drunkenness was expressed as the ability to perform high-risk behaviors that provide a sense of accomplishment for the performer telling (or being told) the tale later. Risky behavior included anything from picking a fight that you might lose to driving home while intoxicated. The key element of the stories is survival from physical harm or parental (authoritative) repercussion:

I live about 15 miles out of town, so I have to go into town to drink. Driving home every weekend and not getting caught. I was at a red light on Highway 2 , there was nobody there. I'm like, screw this, I'm not going to sit through this red light. Of course, the time I am running this red light there is a cop that pulls out from one of the neighborhoods. I just see the cop, but I said, screw this and I just keep going. Then the traffic was going this way and then the cop had to stop because of the traffic. So I just ran to get away from the cop. I wouldn't have done this if I was sober. It's just something you gotta do. I was scared. My buddy with me was scared. My parents would have castrated me.

Adventure stories play a key function in the male subculture, as they define a hierarchy based on courage and skill. Lyng (1990) labeled such risk-taking activities as "edgework":

The "edge," or boundary line, confronted by the edgeworker can be defined in many different ways: life versus death, consciousness versus unconsciousness, sanity versus insanity, an ordered sense of self and environment versus a disordered self and environment. (p. 857)

Common to all leisure-based edgework activities, argued Lyng (1990), is the notion of competence: "This unique skill, which applies to all types of edgework, is the ability to maintain control over a situation that verges on complete chaos, a situation most people would regard as entirely uncontrollable" (p. 859). Narratives praising 
such skills abound in the drinking stories of the fraternities, in which brothers often retold stories of near disasters, often with laughter and boasting. Adventure stories frame the behavior as risky and increase its magnitude to enhance the accomplishment. Many men stated that they exaggerated their stories to make the situation more interesting, the danger more dramatic, or the behavior more outlandish. The stories told by others had a sense of one-upmanship that spoke of a pride in accomplishment, a medal of honor for the performance of a physical action that had risk of great injury but which was accomplished without significant physical harm. Harris (1995) explained this as a "classical male attribute" that "requires men to be "tough guys"" (p. 151) as a source of masculine acceptance and esteem. An initial sense of habitus is established surrounding behaviors while drunk that become reified story after story; drunk play is rowdy, macho, and dangerous - the more danger, the better. Rather than recalling dangerous behavior critically, the discourse is told as a humorous anecdote, sealing the action from critical thought for the group.

One classic example of this is the homecoming float story, a story that is told in several of the fraternities. One fraternity member shares his house's version of the story:

I remember there was a junior in the house last year when we built our float for Homecoming week and he was out on our deck. It was hooked to our deck, holding it up it was so big and he was out there hammered and jumped on the top of it. And I can remember just watching [him] fall two and a half stories down with this huge float and he just floats through the air and falls down on it, he just kinda gets up and looks around, walks back into the house. I can just remember that float fall away from the house and [name] riding her down to the ground. It was hilarious.

Conversely, there is a clear sense that once the adventure itself has worn off, the motivation to engage in drunken performance rituals also fades. One man stated,

In high school we weren't able to do what we wanted because of our parents. More constricted. Came down here and you can do whatever you want. So I would go out Thursday, Friday, Saturday nights and I'd drink Thursday, Friday and Saturday nights. And then now, I have the right to do whatever I want for a year and a half. The newness has worn off and I just go out when I feel like it. I haven't gone out more than two Thursdays this year. I usually stay home and study. You do what you want then, you don't feel the pressures to go out. You just do it for fun.

The adventure story has specific relevancy to restrictive policies regarding alcohol consumption, a common choice among institutions (Perlman, 1997). As many related in their high school stories, there is a sense that removing the ease of access 
not only heightens the adventure, but also frames the stories of edgework as heroic. Stories of "getting away with" drinking or disruptive behavior continue to dominate the folk history of prohibition for similar reasons, with positive images given of flophouses, bathtub ginmills, and exclusive underground drinking clubs (Hansen, 1995; Moore \& Gerstein, 1981). The current construction of drinking for the collegiate culture has also established a clear frame from which resistance to authority is seen as both positive and respectable, and danger is seen as an unquestioned virtue.

\section{The Stupid Story: Drunkenness as Entertainment}

Many stories focused on the use of drunken performances as a form of entertainment, in which the audience played a crucial role by celebrating comic drunken action or sharing stories of clownish behavior to liven a party when no such entertainment could be found.

The notion of spectators in the culture not only fits well with dramaturgical theory but also highlights an important distinction for the culture-the separation between those who drink and those who get drunk. Those who drink may consume as much alcohol as their body can tolerate without losing control. Those who get drunk consume as much alcohol as brings them to the desired state. This is a significant difference in perspective from the majority of study that views quantity of alcohol consumption as a consistent variable for description or prediction. There was a clear sense from the men that quantity is never an issue or concern. Instead, the issue is effect, and the question for the individual is "Do I wish to be drunk tonight?" If the answer is yes, then the student will consume however much is necessary to enter that state. If no, then the student will restrict alcohol intake to maintain control.

Remaining out of the state of drunkenness has its own advantages. One fraternity member stated,

I think the best is when you're not as drunk as somebody and you're just watching to see how stupid they act. You like realize that's the way you get after a while. The thing is you don't even care.

There is a sense from the interviews that those who drink do so to serve as the audience to those who choose to get drunk. Those getting drunk are the performers, and their performances are meaningful for both the performer and the audience in the movement toward adulthood. The female confederate described this audience-performer relationship by stating,

There is an off-campus party that is just hilarious every time we go to it because of all the people there that are just drinking and the fights that almost occur or whatever. It is just fun to sit around and watch, basically. The girls, too, will go with us, drunk or whatever. Even people that aren't totally drunk, 
but the atmosphere or whatever, will cause them to act a certain way. There are a lot of social drinkers, which aren't drunk, just drinking. Then there are some that are just watching that aren't drinking and then there are the other part that are just gone.

As was the case with the adventure story, there is a sense of pride in the telling of the stupid story, as the story serves an important function for the culture in framing drunkenness as a form of recreational play. Stupid stories are funny; in fact, most said that drinking stories in general were told because they were a form of entertainment. The stories allowed for playful teasing, harmless pranks, or comic actions.

Stupid stories also involve an aspect of vulnerability created from the state of drunkenness. The audience becomes part of the performance by preying on the vulnerability of the drunken man to heighten the amusement. One group shared their favorite activities:

B: Just go in with a marker.

A: You marker head somebody? They pass out, you draw stuff on them. The best one was [name]. He, uh, he got all drunk last year, passed out, and they drew a cat on his face, like whiskers and everything? And he woke up and he went back started partying again and he had no idea what happened to him, he's just having a good time and everyone just laughed at him, because he thinks he's all cool, because he thinks he's the center of attention and but he's got that stuff drawn all over his face.

There is little doubt in such cases that entering a state of vulnerability is expected or factored in the decision to become drunk. In fact, many of the members commented that they felt that drinking was safer in the fraternity because they knew that such play would never be malicious or dangerous. One man summarized these feelings by saying, "I know that being in a fraternity, I know that if I' $m$ in this house and just drunk off my mind, somebody will carry me to my room. Wherein if I was in the dorms or something, I'd just get in trouble." The female confederate added this:

I think the difference in the fraternity is they're laughing at you, but at the same time they are laughing with you. You talk about it later. It's all okay. You're drunk and you like do something funny and you kind of say [to the audience] "what?" You are adding entertainment to the night. Where at an outside party they are solely laughing at you. You are going to leave and not know those people and what they are talking about you or whatever. I don't know, I just think it is kind of different. It's kind of like being with your friends or being with people you don't know. With you friends it's funny, when you are with people you don't know it's dumb or whatever. 
Finally, there is a sense from the stories that although anyone within the Greek culture can become drunk and serve as entertainment, there is a distinct group within each fraternity that are viewed as the "notorious" drunks. These individuals tend to enter the state of drunkenness often, and usually display the most outlandish performances. It is interesting to note that the culture has framed these individuals in such a way as to tolerate them, using their performances as amusement yet also adding commentary in their stories that such behavior is seen by the culture as extreme. As one man stated, "You can do stupid stuff and be funny and you can do stupid stuff and just be annoying." One group discussion illustrated this point:

A: Some people are a little more prone to do stupid things.

B: Coming home from the bars one night, walked by the Union when there was construction being done and the caterpillar was sitting open and this other guy got in it and drove it home.

C: He used like a mailbox key to turn it on. It worked! He was drunk and I can't believe he made it without hitting anything.

B: That is a stupid drunk.

Interviewer: It's not like anyone says we can't let this guy get drunk again?

B: No, no.

In another interview, one man identified himself as one of the "regular" drunks. Most of the stories revolved around him. After telling the stories he commented, "We try to cut people off, but some of us are a lot harder to stop. It's really hard to stop me from drinking." Another young man commented, "I'm socially addicted to alcohol-I can't imagine doing something without it."

The acceptance of the notorious drunk as an entertaining element of the culture speaks again to the creation of habitus, in which the game becomes established as routine, and rules-even those that involve embarrassment or humiliation-are followed without question. Notorious drunks are accepted as part of the fraternity culture. The inherent danger in this form of habitus is that the notorious drinker is never seen as chemically dependent, and intervention is seen as counter cultural. Terms such as alcoholism are rarely if ever used in the fraternity culture, yet many were well aware of their reputation as binge drinkers and of the constant threat of enforced drinking policies.

\section{The Naked or Puking Story:}

Drunkenness as Physical Exploration

A third theme that emerged from the study was that drunken performances and their stories served as a way in which to explore aspects of physicality, including sexuality, physical limits, body functions, and physical evolution. Physical discovery is 
often celebrated and ritualized in drunken performances, particularly those that help men learn more about what their bodies are capable of in relation to other men.

Naked stories were perhaps most common. In each of the fraternities, some form of ritual or spontaneous performances included nakedness, always (and only) for the male audience. Women who might observe the performance were never the directed audience, but might see the action from a vantage point hidden to the actor. Naked stories focus around the exposure of the male genitalia, either as a purposed performance (exposing genitalia to others; showing off) or as a comic vulnerability (uncovering what was normally hidden from others). Most stories revolved around a streaking activity that combined bravery (risk of embarrassment) with drunkenness (careless abandon). One fraternity described an elaborate naked ritual:

Riding the buffer naked. We have a floor buffer-a powered floor buffer? And uh, it's kind of a, what would you say, uh, a house tradition. It used to be right here. You'd ride it right here. You could plug it in to [the plug], and you'd sit on it, on the motor, and you'd grab a hold of it, and you'd see how long you could ride it, like a bullride. And then you'd have like a championship, and it was, you know, just a bunch of drunk guys in the basement, riding a buffer around, and — this used to be tile — and you'd just ride it all over the floor.

Other stories spoke of spontaneous nakedness, in which the state of drunkenness provided an opportunity for exposure. An example of this comes from one man in another house:

Probably one of my best stories is, I really didn't start drinking until I came to college and when I first moved in, one of my roommates was slightly intoxicated and we weren't as bad, but we were telling him we were going to throw him in the shower. But he was fighting us the whole time. But then he agreed with us and took off his clothes and started running around the halls naked.

Another group related:

A: Like birthdays, 20th birthdays. 21st birthdays are usually bar hop. 20th birthday, which just started this year.

B: Come into 20 as you were when you were born. Naked. You have to run in the house naked.

$\mathrm{C}$ : Sometimes you get confused and you just get drunk and take your clothes off. That's okay too [laughing and several people talking].

A: Sometimes you wake up in front of your own underpants, and say wait a minute. 
A second set of discovery stories revolve around body functions, particularly those influenced by the drinking process. These are either discussed as performances (vomiting or urinating in inappropriate places as a performance of drunkenness) or as artifacts of drunkenness (remnants of the occasion). Each fraternity had multiple "puke" or "pee" stories that were often described as classic and which served as key cues for future drunken performances. Such cues would be reenacted by new performers as a sign that they were truly drunk. One group provided several examples:

B: Peeing on your roommate's stereo.

A: Puking on your pledge brother is a classic story. Puking on the ceiling on your way to the bathroom-projectile vomit.

C: Going to do something, do it right [laughter].

A: Peeing in your refrigerator. Peeing on your roommate.

B: There are some stories that are always going to be associated with the house.

Another group shared a different story:

A: What about the girl that pissed in your room?

All: Oh, yeah!!!!! [much laughter].

E: Okay, there's this girl drunk in the hall and she comes over here and get drunk and goes everywhere and get drunk. She's a drinker.

C: She's not allowed in some houses.

E: I somehow, I don't know why I want to drag her to my couch, but I figured she would be safe there. So I'm back in my bed and my other roommate is up in my bed and he wakes me up in the middle of the night. I hear the phone off the hook. NNNnnnnnn. He wakes up and goes look, look, she's peeing! She got up and went to the window that is by the phone and tried to dial something, but it's off the hook. So she just looked around and dropped her drawers and then squats, pees, pulls her pants back up and goes to bed.

Interviewer: Out the window?

E: No, on the floor. We have a nice remembrance of that on the carpet still. Stain.

Finally, self-discovery stories are told around the performance of physical endurance, either to pain, injury, or physical reaction. Many stories relate what seem to be fairly serious injuries yet are described as minor and treated as a discovery of physical awareness and capacity. Though over 20 stories shared this theme, 1 story serves as a general illustration: 
So me and this guy drink for about an hour or so in the basement of [fraternity name]. Then we decide that it would be fun to just box each other. We don't have any gloves. These guys saw me on Sunday. So me and this guy sat there for 45 minutes. If you fell down, you were like real cool about it, but it was just crack each other as hard as you could. I don't understand why we did this. I woke up the next day and my whole jaw hurt to bite down and anytime I lifted both my eyes, like were really bruised right here. I still haven't seen him either.

Many of the stories of physical discovery of endurance also appeared to be gender focused to the masculine subculture and confirmed the role of habitus in masculine forms of play. Most involved aggressive play while drunk that ended with stitches, staples, broken noses, bruises, or other injuries, yet, like in many male sports, the injuries "came with the territory" and were just part of the play. The injuries were certainly not framed as dangerous to the players or provided reasons to eliminate rough drunken play.

Many of the stories express a very clear sense of self-discovery as a positive element of the drinking culture, in which students learn about themselves and their physical capacity. The following story combines several of the elements of self-discovery, and yet frames the incident as comic and positive:

We were having a party this one time and this guy we call "Skip the bartender." One night he decided to mix half-and-half drinks all night for everybody. "This is how we do it in the lounge boys."

Interviewer: Tell me what a half-and-half drink is.

Like half coke, half alcohol. Pretty raunchy, it's terrible. Even when you're drunk, you can taste it [laughter]. So we're having people just fall back and forth all over everything. The ladder gets broken down once again. They seem to catch stuff; the stereo and the CDs fly everywhere. We have one guy out going to the bathroom and puking and go right to bed. Then this other guy thinks he can stay up so he gets more to drink. He's still crashing everywhere. So he decides to go to bed. One of his friends goes to check on him, so they have to carry him, 'cause he says he's going to puke. Goes to the toilet and Ralphs the whole night, but not hitting the toilet. It was there for a good week. We come and look for him two hours later and he's naked on his couch like this. We took pictures.

Physical discovery stories raise an interesting set of meanings about drunkenness that in many ways contradict adult sensibilities. Parental messages such as, "Don't do that or you'll throw up (get hurt, etc.)" seem to have an opposite effect 
here; vomiting or minor injuries, for this group, is a badge of accomplishment, a form of entertainment, and a sign of serious obedience to the culture's unwritten rules about gender, fraternal socialization, and recreation.

\section{The Regretted Sex Story: Drunkenness as a Sexual Trap}

Drunkenness also finds meaning in the performances and stories revolving around sexual encounters. The men of the fraternities provided a consistently different story than those presented by public health researchers such as Wechsler et al. (1993; Wechsler et al., 1998). They tell stories of drunkenness that focus on male bonding rather than female sexual conquest, and speak of sexual encounters as regretful from the perspective that the encounter has occurred with an undesirable women and will yield more teasing by other brothers than it will yield sexual satisfaction. Stated one man, "I would much rather run around naked than be caught with the wrong girl."

It is important, at this point, to note that "sexual encounter as a trap" is a discursive construction, and one worthy of note in addressing the issue of date rape and unwanted sexual advances during collegiate social events involving alcohol. Imbued within the construction are a score of unrealized, unapprised issues regarding sexual interaction as the consummation of the social event, patriarchal attitudes toward women, female subjectivity, and masculine esteem. Yet, it is essential that we recognize, within the cultural habitus of fraternity drinking practices, that these issues are unquestioned, and that stories of victimage create a routine that lives without moral or ethical problems.

Stories of regrettable sexual encounters construct drunkenness as a time of foolish sexual choices for the men, who frame themselves as the victims of a sexual encounter, should one occur. A group conversation under this light helps clarify this frame:

B: There were a couple guys in the house that get on some really ugly, meathead, yeah. There are many.

D: This girl that wasn't too cute.

A: It was about 6:00 a.m. I was up cruising around the house and I open the door.

B: It was her 21st birthday. She's never met him before.

C: I came back with them and we went into your room and they disappeared for like an hour.

A: She spent the night.

D: They came back and then we left.

A: I was insanely drunk, but knew she was still ugly.

B: He was ranking her about $71 / 2$ to 8 . Everybody else was pulling about a 2 or 3 on the dense scale. 
When asking another group about their sexual encounters, another reply expressed the same construction:

B: It happens, we all attract the girls that we wouldn't even think about or give a second glance too.

C: You have to be careful!

B: I would much rather run around naked than be caught with the wrong girl.

A: I would rather have every girl see me naked than wake up the next morning and go what the hell am I doing?

Interviewer: Does it ever turn out well? Do you ever wake up next to a beautiful girl?

A: Nope [laughter and several talking all at once].

Interviewer: It's not the beautiful girl who's getting drunk enough?

A: That's what it seems like. They're not looking for a man.

B: For some reason they leave earlier and the fat ones stay [laughter].

Being caught in a sexual encounter with a stranger was not a performance, but rather an opportunity for the rest of the subculture to perform jesting rituals that poked fun at the foolish choice being made. "Real" romantic encounters that involved a potential relationship were also not shared with the culture but were hidden. At times, when discovered, they would not produce teasing but would be ignored by the group. As one man stated, “There's a jealousy factor. We don't talk about those."

An interesting paradox of control exists surrounding the drunken actions that led to regretted sexual encounters and a strictly followed rule across fraternities not to "find yourself getting on" another brother's girlfriend. Girlfriends are especially protected within the fraternity and are treated with particular respect, because, as one member said, "You may never see that girl again, but you're going to see that brother every day."

Several elements of the construction of sexuality within drunkenness are worthy of note. First, many of the constructions of sexuality mirror other textual cues such as alcohol product advertising. Like many of the product advertisements, sexuality is seen as a gendered activity that views women as a source of pleasure and alcohol as an aphrodisiac. The fantasy presented by the commodification of alcohol is fulfilled; despite the discourse of regret and teasing, rules around sexual encounters are never fully changed, so performances of drunken arousal continue. Also interesting is the reproduction of gender, particularly in the attitude toward women, who are clearly seen as objects to the men, judged by their appearance and approached as the site of sexual activity rather than as a potential relationship. Similar findings became the subject of an ethnography of fraternities by Rhoades 
(1995), who concluded that "as male dominated societies, fraternities represent many of the traditions of patriarchy" (p. 321).

\section{The College Story: Drunkenness as Contextual Behavior}

The final theme emerging from the data surrounds the framing of the entire set of performances. Underlying all other stories is the notion that drunken performances are primarily (undergraduate) college-based actions that serve a key function as a once-in-a-lifetime experience. They are, like college itself, a privileged activity that must be enacted or lost for all eternity. As such, they are a celebration of the college experience as a whole. The social practice also represents the college experience; drunkenness is seen as a key confirmation of having been at the university.

Constructions of the contextualized meaning were evident in both positive (seeing college drinking as a good enactment of the life period) and negative expressions (seeing college drinking as a hegemonic ideology that does not allow for options). One group member stated the following:

I was totally antidrinking [in high school]. It just wasn't worth it if I'd got caught it wouldn't been worth me getting kicked off of all the stuff I was on. In college, I'm a number. They're not worried about me. I got to college and our first weekend down here I got totally hammered. Last year I would get totally smashed and be in bed by 9:00 p.m. Then this year I drink beer and stay up a lot later.

Another student expressed the issue differently, defending his right to binge behavior as a college student:

It's almost like they are trying to take all the fun out of it. But the tone of the campus is changing so much to just become an institution and you are here solely to learn. I think that if you ask the student body I really think you'd get that as the first answer for them to be here.

Some members expressed the role of the specific context, or being present at the university (or with university friends at home) as forcing drunken performances. One man added, "I hardly ever get drunk when I' $m$ at home in the summer or during break. It's just when I come back here."

The practice of conscious or unconscious adjustment also exists as a natural occurrence within the college period for the majority of the men. There is a clear sense among members of the fraternities that the need for drunkenness changes over the course of an academic experience, moving from extreme to moderate as the newness and adventure begins to fade and as the student develops competence in consumption. One brother stated the following: 
You kind of find out what your limits are. You have to find them on your own and you find out what liquors are. The first time I drank, I drank my ass off forever, I had no idea. I didn't know that before.

Several men discussed having to switch from hard alcohol to beer as their choice of beverage to better maintain control and enjoy the evening rather than forget it.

Finally, many of the men point to a number of larger cultural cues that framed college as a time for heavy drinking. Cited were popular films and television programs, parental stories, and general statements about college that sent strong cues for behavior. Getting drunk, many believe, is what is expected of them, and the expectations are offered casually by faculty, parents, alumni, the media, and the marketplace. The antidrunk voice coming from the public health institution is seen as the lone authoritative voice and is easily dismissed as being repressive. The men interviewed believe that it places all the blame on "getting smashed" despite the fact that society tells them that college is the time for such extensive forms of the activity.

\section{IMPLICATIONS AND DISCUSSIONS}

The data gathered from this study suggest a number of implications both for the formation of policy as well as for additional research. Most obvious is the confirmed need for continued exploration of the culture using the language and construction of meaning by the culture itself. As the data suggest, those within the culture have constructed a set of meanings surrounding excessive drinking that frame it as a positive, functional, and necessary activity.

Habitus theory gives us a clearer sense of why, particularly within the fraternity culture, which sets itself apart from the rest of the student body, these stories prohibit critical self-reflection on what is obviously a dangerous set of behaviors. Drinking stories not only limit individual and group reflection of potential danger, but they also serve as a form of protection against counter messages about drinking. It was interesting, for example, to talk with the men about "tragic" stories, questioning why they never discussed the stories in which friends, acquaintances, or classmates faced negative consequences for their actions. Several had shared the incident of a friend who, while drunk at a party in his home, fatally shot himself with a rifle. Others had friends who were hospitalized, injured, or had left school because of poor grades. Yet, these stories were never told because, as the men expressed, they would "bring everybody down."

An obvious parallel exists with the rejection of antibinge drinking messages employed by many of the public health interventions currently underway, which are often seen by the students as authoritative, parental, and designed to "ruin the fun of college." If excessive drinking has been constructed as functional as this study suggests, then modifying behavior would ultimately destroy the social func- 
tions students feel are necessary and important. This supports Turrisi's (1999) finding that college students perceive greater negative consequences in the alternatives to high-risk drinking. These data suggest that sobriety has been signified as a limited route to successful socialization by the college student.

Certainly, discourse among students, although powerful, cannot fully account for the interpretation of excessive drinking as positive. Ultimately, we must take a wider glance at the culture to fully note the strength of the construction. Drinking spaces, commercial messages, and other cultural artifacts support the view that drunkenness has positive social functions. Particularly for men, the interpretation of alcohol consumption being connected to sexual conquest from advertising is almost cliché. Much like the habitus of the fraternity drinker, the commercial message avoids the tragic tale, opting instead to tell stories that show only positive consequences or to frame negative consequences as ultimately entertaining. The message from the public health institution, then, is truly in the minority to the many messages that equate consumption (and particularly overconsumption) as ultimately positive and functional.

Given this construction of meaning, the task now becomes one of determining the multiple sources found throughout the fraternal, collegiate, and general culture in which the message is reified. Ultimately, we must assist students in deconstructing those messages rather than simply enacting and reproducing them. However, doing so will mean going beyond telling "the rest of the story." As was found here, fraternity members worked hard to ignore the tragic stories, avoiding the reality of tragic outcomes in their narratives. Instead, reconstruction of meaning may require the strategic use of mirrors and cues to incorporate competing meanings into the culture. In other words, we must give voice to the many activities that do not involve high-risk consumption, which also provide positive cultural functions and positive social outcomes. Our task may be to find other approaches than identifying the negative consequences of high-risk drinking, but to promote the positive consequences of low-risk or moderate consumption. Furthermore, we must question the bigger picture of the economic and political ideology to determine how these have "articulated" (Hall, 1986) themselves to a larger belief system that is now a part of the drinking culture. We can have a significant impact by helping students recognize how it is the producer who ultimately benefits economically from their excessive drinking, and is painting a picture of problem-free consumption for their own profit rather than for the creation of a positive culture.

Also evident from this data is the sense that tracking the quantity of alcohol consumed — under any research paradigm — becomes a dark alley that provides important but limited insight. Quantity of consumption is simply not within the culture's realm of awareness for two reasons. First, our measurements of quantity consumed provide no insight as they ignore individual tolerance levels or substance strengths (Keeling, 1998). Data here suggest that students have a more holistic sense of consumption - a "time" of consumption such as the Saturday party, 
the game, or the "bar crawl." Many of the students had difficulty tracking their consumption per drink, or refuted the classic four or five drink definition as wholly unrealistic. Scholars, too, have questioned the definition (Bohlman, Meilman, \& Dimeff, 1995). One student stated that he used a six-pack to study (as he believed that it had little or no effect on his ability to complete his work), and although that should cause some real concern for intervention specialists, it also expresses an important difference in the way the target audience views quantity. Second, positive function is expressed in the accomplishment of a state of being, and quantity for the culture is simply a means to an end. Focus on the number of drinks consumed per period of time provides no benchmark when the ultimate goal, as expressed in the discourse (rather than the research) is drunkenness, particularly ritual drunkenness. This conclusion adds further support to the notion that the public health label of binge drinking must be revisited as it implies a policy focus on controlling the consumption of quantity rather than on helping the culture overcome dysfunctional meanings of drunkenness (Gusfield, 1996; Hansen, 1995). Toward this end, the data suggest specific areas of meaning construction that can be targeted, from the connection of drunkenness to sexuality and sexual subjectivity (especially from the standpoint of participating women) to the detachment of negative consequences when relating stories in all mediums.

As is typical of a new area of study, the discovery of cultural meanings found in this study offers more questions than answers, and provides abundant opportunities for future research. One limitation of the study is that the data pool consisted of participants who were similar in race, ethnicity, and other cultural factors. All the participants were from the same university as well. It is unclear, therefore, how much of meaning construction can be attributed to cultural background or geographic region. Certainly, data from other locations and cultural backgrounds might yield richer data.

Second, the study focused heavily on group interviews to elicit narratives rather than using participant observation to hear narratives as they were told in the culture (usually at the beginning of a party) or to observe performances that would later be told as stories. Given college students' current attitudes toward being studied about their drinking and their view of authority as producing repressive alcohol policies, student-aged male confederates might serve the role of participant-observer during episodes of drunkenness as they would be more accepted into the culture. Such observation could verify narratives by comparing them to actual behavior, allowing researchers to better analyze the use of elaboration during storytelling.

Finally, the data exposes only those aspects of culture that are conscious and performed, as the act of storytelling itself can be seen as a performance. Missing, then, are acts of resistance that lie hidden within the culture and are not exposed through a collection of drinking stories. It would be beneficial to create groups of nondrinkers to explore the meanings of drunkenness and strategies of 
resistance for this group. Small references were made to individuals within the fraternity who do not participate in the rituals of drunken performance but who share in the telling of narratives, perhaps to maintain their alliance within the culture. Ultimately, data from this group can suggest alternate interpretations and might empower alternate practices.

\section{ACKNOWLEDGMENTS}

Thomas Workman is the Associate Director for NU Directions, a grant project funded by the Robert Wood Johnson Foundation to reduce high-risk drinking. A version of this article was presented at the 1999 National Communication Association Annual Meeting in Chicago.

\section{REFERENCES}

Anderson, D. (1994). Breaking the tradition on college campuses: Reducing drug and alcohol misuse. Fairfax, VA: George Mason University.

Bohlman, B. B., Meilman, P. W., \& Dimeff, L. A. (1995). Binge drinking in college [Letter to the editor]. The Journal of the American Medical Association, 273(4), 1903-1904.

Borsari, B. E., \& Carey, K. B. (1999). Understanding fraternity drinking: Five recurring themes in the literature, 1980-1998. Journal of American College Health, 48, 30-37.

Bourdieu, P. (1990). In other words: Essays toward a reflexive sociology (M. Adamson, Trans.). Oxford, England: Polity Press.

Burke, K. (1945). A grammar of motives. Berkeley: University of California Press.

Burke, K. (1973). The philosophy of literary form. Berkeley: University of California Press.

Carey, J. W. (1989). Communication as culture: Essays on media and society. New York: Unwin Hyman.

Carey, K. B. (1993). Situational determinants of heavy drinking among college students. Journal of Counseling Psychology, 40, 217-220.

Cashin, J. R., Presley, C. A., \& Meilman, P. A. (1998). Alcohol use in the Greek system: Follow the leader? Journal of Studies on Alcohol, 59, 63-71.

Corbin, W. R., McNair, L. D., \& Carter, J. (1996). Self-esteem and problem drinking among male and female college students. Journal of Alcohol and Drug Education, 42, 1-13.

Donohew, L., Hoyle, R. H., Clayton, R. R., Skinner, W. F., Colon, S. E., \& Rice, R. E. (1999). Sensation seeking and drug use by adolescents and their friends: Models for marijuana and alcohol. Journal of Studies on Alcohol, 60, 622-628.

Ewing, J. A., \& Rouse, B. A. (Eds.). (1978). Drinking: Alcohol in American society-Issues and current research. Chicago: Nelson-Hall.

Fiske, J. (1989). Reading the popular. New York: Unwin Hyman.

Goffman, E. (1959). The presentation of self in everyday life. Garden City, NY: Doubleday.

Gross, W. C. (1993). Gender and age differences in college students' alcohol consumption. Psychological Reports, 72, 211-217.

Gusfield, J. R. (1989). The bridge over separated lands: Kenneth Burke's significance for the study of social action. In H. W. Simons \& T. Melia (Eds.), The legacy of Kenneth Burke (pp. 28-54). Madison: University of Wisconsin Press. 
Gusfield, J. R. (1996). Contested meanings: The construction of alcohol problems. Madison: University of Wisconsin Press.

Haines, M. P. (1996). A social norms approach to preventing binge drinking at colleges and universities (Publication No. ED/OPE/96-18). Newton, MA: The Higher Education Center for Alcohol and Other Drug Prevention, Education Development Center, U.S. Department of Education.

Hall, S. (1986). On postmodernism and articulation: An interview with Stuart Hall. Journal of Communication Inquiry, 10, 45-60.

Hansen, D. J. (1995). Preventing alcohol abuse: Alcohol, culture and control. Westport, CT: Praeger.

Harrington, N. G., Brigham, N. L., \& Clayton, R. R. (1999). Alcohol risk reduction for fraternity and sorority members. Journal of Alcohol Studies, 60, 521-527.

Harris, I. M. (1995). Messages men hear: Constructing masculinities. Bristol, PA: Taylor \& Francis.

Heath, D. B., \& Cooper, A. M. (1981). Alcohol use and world cultures: A comprehensive bibliography of anthropological resources. Toronto, Canada: Addiction Research Associates.

Keeling, R. P. (1998). Drinking in college: The politics of research and prevention. Journal of American College Health, 47, 51-56.

Klein, H. (1994). Changes in college students' use and abuse of alcohol, and in their attitudes toward drinking over the course of their college years. Journal of Youth and Adolescence, 23, 251-270.

Larimer, M. E., Irvine, D. L., Kilmer, J. R., \& Marlatt, G. A. (1997). College drinking and the Greek system: Examining the role of perceived norms for high-risk behavior. Journal of College Student Development, 38, 587-598.

Lederman, L. C. (1993). "Friends don't let friends beer goggle": The use and abuse of alcohol among college students. In R. E. Berlin (Ed.), Case studies in health communication (pp. 161-174). Hillsdale, NJ: Lawrence Erlbaum Associates, Inc.

Lichtenfield, M., \& Kayson, W. A. (1994). Factors in college students' drinking. Psychological Reports, 74, 927-930.

Lieblich, A., Tuval-Mashiach, R., \& Zilber, T. (1998). Narrative research: Reading, analysis, and interpretation. Thousand Oaks, CA: Sage.

Lucaites, J. L., \& Condit, C. M. (1985). Re-constructing narrative theory: A functional perspective. Journal of Communication, 35, 90-108.

Lyng, S. (1990). Edgework: A social psychological analysis of voluntary risk taking. American Journal of Sociology, 95, 851-886.

Meilman, P. W., Leichliter, J. S., \& Presley, C. A. (1999). Greeks and athletes: Who drinks, more? Journal of American College Health, 47, 187.

Mills, J. K., Sirgo, V. I., \& Hartjes, D. T. (1993). Perceptions of excessive alcohol consumption in stressful and non-stressful situations among undergraduates. The Journal of Psychology, 127, 543-546.

Monroe, J. (1996). Binge drinking: Alcohol use among college students. Current Health 2, 22(9), $26-29$.

Moore, M. H., \& Gerstein, D. R. (Eds.). (1981). Alcohol and public policy: Beyond the shadow of prohibition. Washington, DC: National Academy Press.

Perkins, H. W., Meilman, P. W., Leichliter, J. S., Cashin, J. R., \& Presley, C. A. (1999). Misperceptions of the norms for the frequency of alcohol and other drug use on college campuses. Journal of American College Health, 47, 253-258.

Perlman, S. E. (1997, December 1). Searching for solutions. New York Newsday, p. A23.

Rhoads, R. A. (1995). Whales tales, dog piles, and beer goggles: An ethnographic case study of fraternity life. Anthropology and Education, 26, 306-323.

Robbins, C. (1993). Between paradigms: A half-century of sociological research on alcohol. Contemporary Sociology, 22, 367-369.

Slicker, E. K. (1997). University students reasons for NOT drinking: Relationship to alcohol consumption level. Journal of Alcohol and Drug Education, 42(2), 83-101.

Smeaton, G. L., Josiam, B. M., \& Dietrich, U. C. (1998). College students' binge drinking at a beach-front destination during spring break. Journal of American College Health, 46, 247-254. 
Straus, R., \& Bacon, S. D. (1953). Drinking in college. New Haven, CT: Yale University Press.

Turrisi, R. (1999). Cognitive and attitudinal factors in the analysis of alternatives to binge drinking. Journal of Applied Social Psychology, 29, 1512-1514.

Wechsler, H., Dowdall, G. W., Davenport, A., \& DeJong, W. (1993). Binge drinking on campus: Results of a national study (Bulletin produced by the Higher Education Center for Alcohol and Other Drug Prevention). Washington, DC: U.S. Department of Education.

Wechsler, H., Dowdall, G. W., Davenport, A., \& DeJong, W. (1994). Health and behavioral consequences of binge drinking in college. Journal of the American Medical Association, 272, $1672-1677$.

Wechsler, H., Dowdall, G. W., Maener, G., Gledhill-Hoyt, J., \& Lee, H. (1998). Changes in binge drinking and related problems among American college students between 1993 and 1997: Results of the Harvard School of Public Health College Alcohol Study. Journal of American College Health, 47, $57-69$.

Wechsler, H., Isaac, N., Grodstein, F., \& Sellers, D. E. (1994). Continuation and initiation of alcohol use from the first to the second year of college. Journal of Studies on Alcohol, 55, 41-46.

Wechsler, H., Lee, J. E., Kuo, M., \& Lee, H. (2000). College binge drinking in the 1990s: A continuing problem. Journal of American College Health, 49, 57-64.

Wechsler, H., Molnar, B. E., Davenport, A. E., \& Baer, J. S. (1999). College alcohol use: A full or empty glass? Journal of American College Health, 47, 247-252.

Williams, A., \& Clark, D. (1998). Alcohol consumption in university students: The role of reasons for drinking, coping strategies, expectancies, and personality traits. Addictive Behavior, 23, 371-379.

Workman, T. A. (1998, November). The construction of binge drinking as a social problem in America. Paper presented at the annual meeting of the National Communication Association, New York. 